\title{
Isolation and identification of Enset wilt disease causing bacteria using 16S rRNA Gene Sequence samples collected from Gurage zone, Ethiopia
}

\author{
Belay TILAHUN ${ }^{1}$, Degisew YINUR ${ }^{2}$, Dejene ZENABU² and Flagot Mola MENESHA ${ }^{2}$ \\ ${ }^{1}$ Institute of Biotechnology, University of Gondar, P. O. Box 196, Gondar, Ethiopia \\ ${ }^{2}$ Department of Biotechnology, College of Natural and Computational Sciences, Wolkite University, P. O. Box 07, Wolkite, Ethiopia. \\ Corresponding author's Email: belayt21@gmail.com
}

\section{ABSTRACT}

Introduction. Xanthomonas campestris is an important bacterium responsible for bacterial wilt disease, which causes predominantly a serious loss in enset production. In some ensetgrowing areas of Ethiopia, farmers are enforced to replace perennial enset plants with annual crops because of this disease devastates enset production. Aim. Therefore, the study aimed to identify the molecular diversity of bacterial wilt disease causing bacteria from infected enset plants that were collected from the Gurage Zone, using the 16S rRNA gene sequence. Methods. 60 infected enset samples were collected from infected enset plants. Presumptive identification of the bacterium was done through biochemical tests. 16S rRNA genes of bacterial isolates were amplified using the bacteria universal primers and the amplified products were sequenced at MRC-Holland, Amsterdam. Sequence analysis and comparison were conducted to identify the isolated microbes into species and strain levels. Results. Based on the biochemical tests, 18 bacterial isolates were motile, indole negative as well as citrate and catalase positive and they were hydrolyzed starch. The sequence analysis revealed that from 18 bacterial isolates 17 of them were identified as Xanthomonas campestris of different strains and one isolate was identified as an uncultured bacterium. In this study, different Xanthomonas campestris strains that have different virulence factors were identified in the study area. To effectively control and manage bacterial wilt disease of enset plant, it is important to examine antipathogenic agent or biological control mechanisms for all Xanthomonas campestris strains. Additionally, determining plant bacterial interaction using molecular tools and identify the virulence genes are also beneficial.

\author{
Original Article \\ PII: S225199392000007-10 \\ Rec. 23 May 2020 \\ Rev. 29 June 2020 \\ Pub. 25 July 2020
}

\section{Keywords}

Xanthomas sp.,

Enset,

16srRNA gene,

DNA sequencing,

Wilt disease

\section{INTRODUCTION}

Xanthomonas campestris is one of the most common bacteria responsible for bacterial wilt disease which attacks and kills enset plants at any developmental stage [1]. It causes predominantly a serious loss in enset production in which the farmer has already invested land, labor, and resources for several years [2]. Such situations have caused farmers to replace enset plants with annual crops in the southern region of the country (Ethiopia). Enset growing regions are densely populated with very small land coverage (average of $0.17 \mathrm{ha}$ ). However, such a replacement of enset by annual crops on such a small plot cannot fulfill the food demand of the region [2; 3].

Among the genus Xanthomonas bacteria Xanthomonas campestris which is rod-shaped, gram-negative bacteria and creamy and light yellow mucoid circular colonies on YDC agar [1] with growth temperature from 25-30 ${ }^{\circ} \mathrm{C}$, causes the serious disease of enset and banana wilt in the most Africa countries [3]. The disease appears on any part of enset but mostly appears on youngest leaves that show greyish-brown at the tip the plant leaves [1]. In different agroecology, the disease is disseminated and the production of enset has been decreased in the areas where enset is growing and used as a staple food [3]. Thereof, it causes the problem of food insecurity in the enset growing regions of Ethiopia [4].

There are variations among the Xanthomonas campestris strains regarding to their pathogenicity which leads to great damage in crop production and makes it more complicated to manage the disease [3-5]. The ddiscrepancy among Xanthomonas campestri strains may have different virulent factors and difficult to screen resistance enset clones. Selections of resistant clones are non-reproducible when testing disease resistant enset clones by different Xanthomonas campestri isolates. Thus, to develop an effective controlling mechanism of wilt disease which causes by Xanthomonas campestri and to screen resistant enset cones, studying the diversity of 
Xanthomonas campestris is needed. In order to overcome the bottle neck, this study was planned to assess the molecular diversity of available strain from infected enset plants which were collected in the study area.

\section{MATERIAL AND METHODS}

\section{Isolation and selection of bacteria}

A total of 60 infected enset samples was collected aseptically from infected enset plants. Those samples were obtained from different enset plant varieties that were found ten kebele of three woredas (Gumere Woreda, Cheha Woreda, and Ezia woreda). Then the samples were transported to Wolkite University Biotechnology Department Laboratory. Then after surface sterilization, $10 \mathrm{mg}$ of tissues from each infected plant samples were transferred into $90 \mathrm{ml}$ sterile $0.1 \%$ peptone water containing conical flask and homogenized by vortex for 10-15 min. From appropriate serial dilutions, $0.1 \mathrm{ml}$ Aliquots were spread plated onYDC agar and incubated at $28^{\circ} \mathrm{C}$ for $48 \mathrm{~h}$. The pure isolates were maintained on YDC agar slants at $4^{\circ} \mathrm{C}$ and sub-culture every four weeks was done until biochemical and molecular characterization was carried out [6].

\section{Biochemical characterization of bacterial isolates}

The morphological characterizations of bacterial isolates were determined according to their cultural characteristics using a microscope [7- 8]. Biochemical characterizations such as gram, oxidase, catalase, citrate, indole, $\mathrm{H}_{2} \mathrm{~S}$, VP, citrate, catalase, and methyl red tests) were conducted for each bacterial isolates [9-11].

\section{Starch hydrolysis test}

Bacterial isolates were streak plated on nutrient agar plates containing $0.2 \%$ soluble starch (w/v) and incubated at $30^{\circ} \mathrm{C}$ until heavy growth occurred. Then plates were flooded with IKI solution (iodine, 1g; potassium iodide, 2g; distilled water, $100 \mathrm{ml}$ ) and the clear zone around a colony was recorded as positive reaction [12].

\section{Amplification of 16S rRNA gene}

The genomic DNA of bacterial isolates was extracted using DNeasy DNA Extraction kit, Qiagen [13- 14]. To amplify the 16S rRNA gene of each bacterial isolate, PCR reaction mixtures (50 $\mu \mathrm{l}$ ) which contained $1 \mu$ l of the extracted DNA, $5 \mu \mathrm{l}$ dNTPs, $1 \mu \mathrm{l}$ of each of primers rDl (5'-AGA GTT TGA TCC TGG CT C AG-3') and fDl (5'-AAG GAG GTG ATC CAG CC-3') [15-16], $1 \mu \mathrm{l}$ of Taq DNA polymerase (Fermentas, St. Leon- Rot, Germany), $5 \mu \mathrm{l}$ PCR buffer and reverse osmosis purified water were used. The PCR reaction was programed as initial denaturation at $95^{\circ} \mathrm{C}$ for $60 \mathrm{sec}$, followed by 35 cycles of denaturation at $94^{\circ} \mathrm{C}$ for $60 \mathrm{sec}$, primer annealing at $51^{\circ} \mathrm{C}$ for 30 sec and primer extension at $72^{\circ} \mathrm{C}$ for $60 \mathrm{sec}$ with a final extension at $72{ }^{\circ} \mathrm{C}$ for $60 \mathrm{sec}$. Then, the PCR products of the 16S rRNA gene were separated by gel electrophoresis using $1 \%$ agarose gel and $1 \mu L$ loading dye with $5 \mu L$ PCR products and stained with ethidium bromide for gel documentation [16-17].

\section{Nucleotide sequencing and sequence analyses}

The 16S rRNA gene PCR product of each bacterial isolate was sequenced by automated DNA sequencer (ABI model 377; Applied Biosystems), MRC-Holland, Amsterdam [16].

\section{Phylogenetic analysis}

After the raw DNA sequences were edited using the FinchTV package and consensus sequences were obtained. The sequences were compared with the NCBI DNA database using the BLAST search [16- 19]. Then sequences were then aligned using Clustalx 2.1 [19] and phylogenetic tree was constructed using MEGA 7 [1619].

\section{RESULT AND DISCUSSION}

\section{Bacterial isolation and morphological characteristics}

From 60 infected enset samples, 18 bacterial isolates were obtained and purified. They were yellowish on nutrient agar, circular in shape, shiny, motile and all of them were also Gram-negative. Most of the isolates had slimy mucoid yellowish, therefore; results were in line with Tsehay [1] and Welde-Micheal et al. [2]. As indicated 
in Aritua et al. [20] the bacterium is described as a motile, gram-negative rod, possessing a single polar flagellum and producing typical yellow, convex, mucoid colonies on nutrient agar and YDC media. Regarding on the morphological characteristics or their colony morphology results, 18 bacterial isolates which were resembled Xanthomonas spp were selected [20].

\section{Biochemical characterization of bacterial isolates}

Motility is one of an important differentiating tools in bacteria, has long been recognized as a biological characteristic of microorganisms [4]. All 18 bacterial isolates were motile and indole negative which was unable to breakdown tryptophan to indole. Likewise, all isolates were citrate positive, which they change the color of the medium (deep green) to blue indicates the ability of to metabolize citrate. Besides, all isolates were catalase positive; produced bubbles when the colony of each isolate was dissolved in a few drops of $3 \% \mathrm{H}_{2} \mathrm{O}_{2}$ which is supported by Haile et al. [4] (Table 1) report. After the plates were flooded with IKI solution clear zone around a colony was recorded as a positive reaction. The clear zone indicates the level of starch hydrolysis capacity of isolates (Figure 1). Potential isolates can produce large clear zone and indicate complete hydrolysis of starch. All isolates were able to hydrolyze starch and the clear zones were also observed.

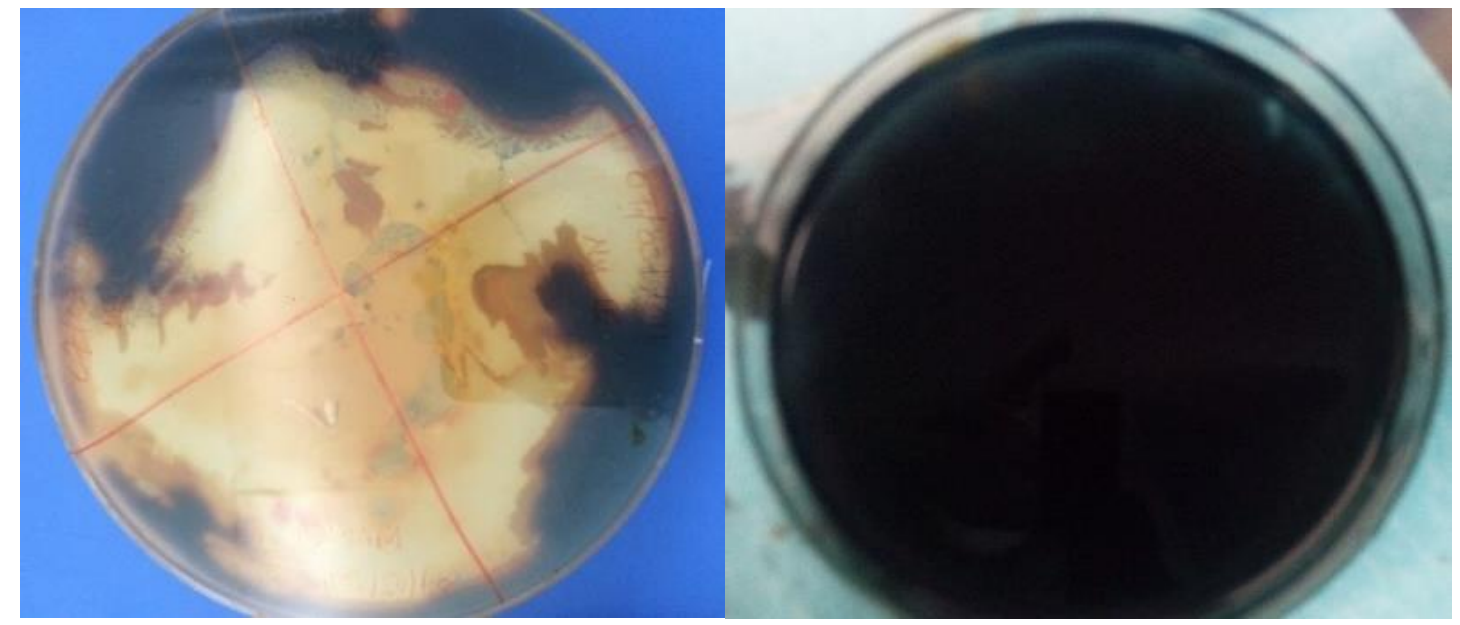

Figure 1. Clear zone observed around bacterial isolates

\section{Molecular Characterization of bacterial isolates}

Amplification of 16S rRNA gene of bacterial isolates. The PCR product of all bacterial isolates was shown in Figure 2 and all the isolates were shown to have PCR amplified fragments with around 150obp size [16].

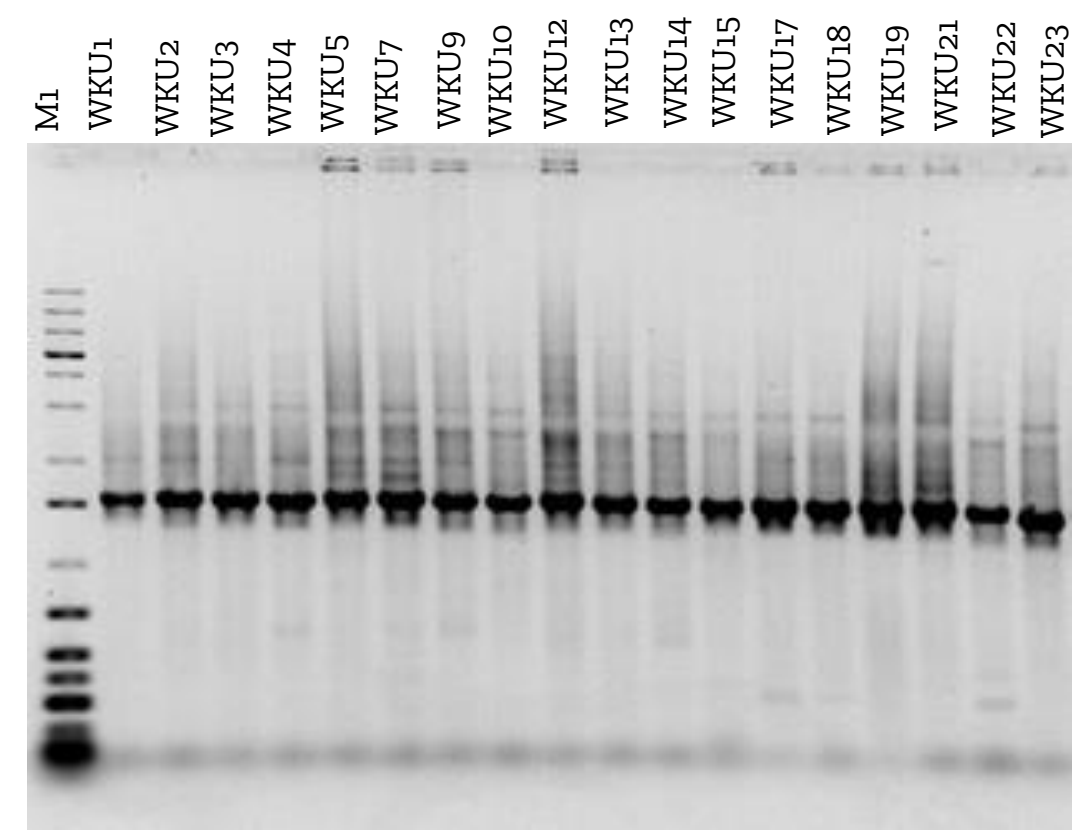

Figure 2. $P C R$ amplification $16 s$ rRNA using $\mathrm{rDl}$ and $\mathrm{fDl}$ bacterial universal primers, $\mathrm{Ml}$; $1 \mathrm{~kb} \mathrm{DNA}$ ladder, amplicon size; 1500bp. 


\section{S rRNA gene of bacterial sequence analyses}

After all the raw the 16S rRNA gene sequences of 18 bacterial isolates were edited using the FinchTV package, consensus sequences (edited sequence) were blasted in Gen Bank of NCBI. Samples which showed from $92-100 \%$ percent of homology were identified as shown in Table 2. According to this study, the seventeen bacterial isolates were identified as Xanthomonas campestris, one isolate was identified as Pseudomonas protegens, one isolate was also identified as Bacillus subtilis and four isolates were also identified as uncultured bacteria.

The seventeen bacterial isolates were found to be the genus Xanthomonas, of which WKU1, WKU3, WKU17 and WKU18 were belongs to Xanthomonas campestris pv. campestris XCC-C7 with $100 \%$ of sequence homology. WKU2, WKU9, WKU10, WKU13, WKU14 and WKU15 were Xanthomonas campestris strain ATCC 33913 with 100\% of homology. WKU4 and WKU21 were identified as Xanthomonas campestris strain Xan-E1with $92 \%$ and $100 \%$ of homology respectively.

WKU7 and WKU12 were identified as Xanthomonas campestris strain LMG 568; WKU19 and WKU22 were identified as Xanthomonas campestris strain PgBe189 and WKU23 were identified as Xanthomonas campestris strain with 100\% of homology. As Young et al. [21] indicated that the isolates identified as Xanthomonas species by Biolog were confirmed as Xanthomonas campestris using the GspDm primers, sequence-based phylogenetic tree and pathogenicity tests. The diversity of Xanthomonas bacteria in banana (similar to a false banana, enset) which was studied by Studholme et al. [22] has concurred with this study. Hence, identified diversity of Xanthomonas within the enset plant, reveals that there has been an evolution of Xanthomonas species from time to time.

Maximum likelihood method of Tamura and Nei [19] was used to infer the evolutionary history of identified bacterial species. The highest log likelihood (-1679.15) is shown in the tree. The tree is drawn to scale, with branch lengths measured in the number of substitutions per site as shown in Figure 3. There were a total of 994positions in the final dataset. Evolutionary analyses were conducted in MEGA7 [23].

Molecular identification of Xanthomonas spp. from infected enset using 16s rRNA sequence was identified Xanthomonas campestris which is a more precise and accurate technique for identification of bacterial isolates. This is supported by Adriko et al., [24] the use of multiple tools for precise identification and characterization of Xanthomonas bacteria in bananas and elucidates the benefit of this microbial diversity in the management of bacterial wilt disease. Owing to the variable phenotypic and genotypic characteristics of bacteria, serving for their identification, their diagnosis often requires the use of complementary methods [25].

Table 1. Biochemical characteristics of the bacterial isolates

\begin{tabular}{|c|c|c|c|c|c|c|c|c|c|c|}
\hline \multirow{2}{*}{ No. } & \multirow{2}{*}{$\begin{array}{l}\text { Sample } \\
\text { code }\end{array}$} & \multirow{2}{*}{$\begin{array}{l}\text { Bacterial } \\
\text { isolates }\end{array}$} & \multicolumn{8}{|c|}{ Biochemical tests } \\
\hline & & & $\begin{array}{l}\text { Gram } \\
\text { test }\end{array}$ & $\begin{array}{l}\text { KOH } \\
\text { Test }\end{array}$ & $\begin{array}{c}\text { Starch } \\
\text { hydrolysis }\end{array}$ & Citrate & $\begin{array}{c}\text { Catalase } \\
\text { test }\end{array}$ & $\begin{array}{l}\mathrm{H}_{2} \mathrm{~S} \\
\text { test }\end{array}$ & $\begin{array}{c}\text { Indole } \\
\text { test }\end{array}$ & Motility \\
\hline 1. & BB9 & WKUO4 & - & + & + & + & + & + & - & Motile \\
\hline 2. & YM18 & WKUos & - & + & + & + & + & + & - & Motile \\
\hline 3. & $\mathrm{XXl}(\mathrm{A})$ & WKUO7 & - & + & + & + & + & + & - & Motile \\
\hline 4. & BN7 & WKU12 & - & + & + & + & + & + & - & Motile \\
\hline 5. & 28 & WKUO2 & - & + & + & + & + & + & - & Motile \\
\hline 6. & $\mathrm{BB7SH}$ & WKUog & - & + & + & + & + & + & - & Motile \\
\hline 7. & WY1 & WKU1O & - & + & + & + & + & + & - & Motile \\
\hline 8. & $\mathrm{XY}_{5}$ & WKU13 & - & + & + & + & + & + & - & Motile \\
\hline 9. & AY13 & WKU14 & - & + & + & + & + & + & - & Motile \\
\hline 10. & $\mathrm{AV}_{13}(\mathrm{~A})$ & WKU15 & - & + & + & + & + & + & - & Motile \\
\hline 11. & WY3 & WKUOI & - & + & + & + & + & + & - & Motile \\
\hline 12. & $\mathrm{BB} 10$ & WKUo3 & - & + & + & + & + & + & - & Motile \\
\hline 13. & TZ11 & WKU17 & - & + & + & + & + & + & - & Motile \\
\hline 14. & YN16 & WKU18 & - & + & + & + & + & + & - & Motile \\
\hline 15. & 35 & WKU22 & - & + & + & + & + & + & - & Motile \\
\hline 16. & $\mathrm{XX} 2$ & WKU19 & - & + & + & + & + & + & - & Motile \\
\hline 17. & 29 & WKU21 & - & + & + & + & + & + & - & Motile \\
\hline 18. & $\mathrm{NM} 16 \mathrm{SH}$ & WKU23 & - & + & + & + & + & + & - & Motile \\
\hline
\end{tabular}


Table 2. Identification of bacteria isolated from Enset as revealed by partial 16S rRNA gene sequence BLAST search.

\begin{tabular}{|c|c|c|c|c|c|c|c|}
\hline No. & Sample code & $\begin{array}{l}\text { Bacterial } \\
\text { isolates }\end{array}$ & $\begin{array}{l}\text { Infected Enset } \\
\text { type (local name) }\end{array}$ & $\begin{array}{c}E \\
\text { value }\end{array}$ & \% homology & $\begin{array}{l}\text { NCBI Accession } \\
\text { Number }\end{array}$ & ID based on NCBI BLAST \\
\hline 19. & BB9 & WKUo4 & Agadi & o & $92 \%$ & KT156667 & Xanthomonas campestris strain Xan-T1 \\
\hline 20. & YM18 & WKUo5 & Ginbio & 0 & $100 \%$ & GU272305 & Uncultured bacterium clone CF12 \\
\hline 21. & $\mathrm{XX}(\mathrm{A})$ & WKUo7 & Agadi & o & $100 \%$ & NR119219 & Xanthomonas campestris strain LMG 568 \\
\hline 22. & BN7 & WKU12 & Ameratye & o & $100 \%$ & NR119219 & Xanthomonas campestris strain LMG 568 \\
\hline 23. & 28 & WKUo2 & Agadi & o & $100 \%$ & NRo74936 & Xanthomonas campestris strain ATCC 33913 \\
\hline 24. & BB7SH & WKUog & Ankafuye & 0 & $100 \%$ & NR074936 & Xanthomonas campestris strain ATCC 33913 \\
\hline 25. & WY1 & WKU1O & Ankafuye & o & $100 \%$ & NR074936 & Xanthomonas campestris strain ATCC 33913 \\
\hline 26. & $\mathrm{XY}_{5}$ & WKU13 & Yshrakinki & o & $100 \%$ & NRo74936 & Xanthomonas campestris strain ATCC 33913 \\
\hline 27. & $\mathrm{AY} 13$ & WKU14 & Yshrakinki & o & $100 \%$ & NRo74936 & Xanthomonas campestris strain ATCC 33913 \\
\hline 28. & $\mathrm{AV} 13(\mathrm{~A})$ & WKU15 & Astara & o & $100 \%$ & NRo74936 & Xanthomonas campestris strain ATCC 33913 \\
\hline 29. & WY3 & WKUol & Ankafuye & 0 & $100 \%$ & MN108237 & Xanthomonas campestris pv. campestris XCC-C7 \\
\hline 30. & $\mathrm{BB} 10$ & WKUo3 & Ginbio & o & $100 \%$ & MN108237 & Xanthomonas campestris pv. campestris XCC-C7 \\
\hline 31. & TZ11 & WKU17 & Ameratye & o & $100 \%$ & MN108237 & Xanthomonas campestris pv. campestris XCC-C7 \\
\hline 32. & YN16 & WKU18 & Astara & o & $100 \%$ & MN108237 & Xanthomonas campestris pv. campestris $\mathrm{XCC}-\mathrm{C}_{7}$ \\
\hline 33. & 35 & WKU22 & Separa & 0 & $100 \%$ & $\mathrm{MH} 211280$ & Xanthomonas campestris strain PgBe189 \\
\hline 34. & $\mathrm{XX} 2$ & WKU19 & Ameratye & o & $100 \%$ & MH211280 & Xanthomonas campestris strain PgBe189 \\
\hline 35. & 29 & WKU21 & Separa & o & $100 \%$ & KT156666 & Xanthomonas campestris strain Xan-El \\
\hline 36. & $\mathrm{NM} 16 \mathrm{SH}$ & WKU23 & Separa & 0 & $100 \%$ & EF059753 & Xanthomonas campestris \\
\hline
\end{tabular}


GU272305.1) Uncultured bacterium clone CF12

WKU21) Xanthomonas campestris strain Xan-E1

NR 074936.1)Xanthomonas campestris strain ATCC 33913

KT156667.1) Xanthomonas campestris strain Xan-E1

WKU01) Xanthomonas campestris pv. campestris XCC-C7

WKU22) Xanthomonas campestris strain PgBe189

WKU04) Xanthomonas campestris strain Xan-T1

WKU07) Xanthomonas campestris strain LMG 568

WKU05) Uncultured bacterium clone CF12

99

WKU18) Xanthomonas campestris pv. campestris XCC-C7

WKU09) Xanthomonas campestris strain ATCC 33913

WKU10) Xanthomonas campestris strain ATCC 33913

MN108237.1) Xanthomonas campestris pv. campestris XCC-C7

WKU02) Xanthomonas campestris strain ATCC 33913

WKU03) Xanthomonas campestris pv. campestris XCC-C7

WKU19) Xanthomonas campestris strain PgBe189

NR 119219.1) Xanthomonas campestris strain LMG 568

WKU12) Xanthomonas campestris strain LMG 568

EF059753.1) Xanthomonas campestris

MH211280.1) Xanthomonas campestris strain PgBe189

WKU17) Xanthomonas campestris pv. campestris XCC-C7

WKU15) Xanthomonas campestris strain ATCC 33913

WKU23) Xanthomonas campestris

WKU13) Xanthomonas campestris strain ATCC 33913

WKU14) Xanthomonas campestris strain ATCC 33913

\section{$\stackrel{10020}{0.0010}$}

Figure 3. Phylogenetic analysis based 16s rRNA gene sequences of bacterial strains isolated from Enset; coded as WKU followed by numbers and reference bacterial strains using the Maximum Likelihood method.

\section{CONCLUSION}

In this study, important strains of Xanthomonas spp which were found in the study area were identified. Sequencing based phylogenetic highlight relationships and possible interactions among the diverse bacteria populations in a plant system were also recognized. Therefore, the result of this study indicated that various Xanthomonas campestris strains are responsible for bacterial wilt disease of enset plant. Identification of these isolates could contribute valuable information for the understanding of enset plant pathogenic interaction and to develop controlling mechanisms of the pathogen. Moreover, Understanding the dynamics of Xanthomonas spp in enset and could provide insight into the effect of microbial interactions on BXW disease development as well possibly using some of these endophytic bacteria as bio control agents.

\section{DECLARATIONS}

\section{Acknowledgments}

First of all, I would like to thank the Research and community service of Wolkite University, Ethiopia for their financial support of this study. I would like also thank Dr. Zewdu Terefwork and Prof. Garry Wessel for their unlimited support for sequence analysis.

\section{Authors' contributions}

B.T. performed all the laboratory works, collected samples and materials, analyzed the data and wrote the manuscript. D.Y. performed molecular laboratory works, wrote and edited the manuscript. D.Z. and F.M. 
collected samples, performed some part of laboratory work and involved in data records. All Authors read and agreed on the first manuscript.

\section{Conflicts of interest}

The Authors declare no conflict of interest.

\section{Data availability statement}

All the data of study are available from the corresponding author.

\section{REFERENCES}

1. Tsehay M. Studies on genetic and phenotypic variation between enset and banana isolates of bacterial wilt pathogen (Xanthomonas campestris pv. musacearum) in Ethiopia (Doctoral dissertation, Master thesis], Ambo University, Ambo, Ethiopia). Google Scholar

2. Welde-Michael G, Bobosha K, Blomme G, Addis T, Mengesha T, Mekonnen S. Evaluation of enset clones against enset bacterial wilt. African Crop Science Journal. 2008;16(1). Google Scholar, DOI: 10.4314/acsj.v16i1.54348

3. Handoro F, Michael GW. Evaluation of enset clone meziya against enset bacterial wilt. In8th African Crop Science Society Conference, El-Minia, Egypt, 27-31 October 20072007 (pp. 887-890). African Crop Science Society. Google Scholar,

4. Haile B, Adugna G, Handoro F. Physiological characteristics and pathogenicity of Xanthomonas campestris pv. musacearum strains collected from enset and banana in Southwest Ethiopia. African Journal of Biotechnology. 2014;13(24). Google Scholar, DOI: 10.5897/AJB2014.13794

5. Aritua V, Nanyonjo A, Kumakech F, Tushemereirwe W. Rep-PCR reveals a high genetic homogeneity among Ugandan isolates of Xanthomonas campestris pv musacearum. African Journal of biotechnology. 2007;6(3). Google Scholar, PDF

6. Desiye A, Abegaz K. Isolation, characterization and identification of lactic acid bacteria and yeast involved in fermentation of teff (Eragrostis tef) batter. Advanced Research in Biological Sciences. 2013;3:36-44. Google Scholar, PDF

7. Hoque MZ, Akter F, Hossain KM, Rahman MS, Billah MM, Islam KM. Isolation, identification and analysis of probiotic properties of Lactobacillus spp. from selective regional yoghurts. World J Dairy Food Sci. 2010 Jan 1;5(1):39-46. Google Scholar, PDF

8. Menconi A, Kallapura G, Latorre JD, Morgan MJ, Pumford NR, Hargis BM, Tellez G. Identification and characterization of lactic acid bacteria in a commercial probiotic culture. Bioscience of Microbiota, Food and Health. 2014;33(1):25-30. Google Scholar, https://doi.org/10.12938/bmfh.33.25

9. Hemraj V, Diksha S, Avneet G. A review on commonly used biochemical test for bacteria. Innovare J Life Sci. 2013;1(1):1-7. Google $\underline{\text { Scholar }}$

10. Murray PR, Baron EJ, Pfaller MA, Tenover FC, Yolken RH, Morgan DR. Manual of Clinical Microbiology (6th edn). Trends in microbiology. 1995;3(11):449-. Google Scholar

11. MacFaddin JF. Biochemical Tests for Identification of Medical Bacteria, Williams and Wilkins. Philadelphia, PA. 200o:113.Google $\underline{\text { Scholar }}$

12. Rafi A, Hameed A, Akhtar MA, Sohail K, Shahid M, Fahim M. IDENTIFICATION AND CHARACTERIZATION OF XANTHOMONAS ORYZAE PV ORYZAE IN NORTH-WEST OF PAKISTAN. Sarhad Journal of Agriculture. 2013 Sep 30;29(3). Google Scholar

13. Gevers D, Huys G, Swings J. Applicability of rep-PCR fingerprinting for identification of Lactobacillus species. FEMS microbiology letters. 2001 Nov 1;205(1):31-6.Google Scholar, https://doi.org/10.1111/j.1574-6968.2001.tblog21.x

14. Janda JM, Abbott SL. 16S rRNA gene sequencing for bacterial identification in the diagnostic laboratory: pluses, perils, and pitfalls. Journal of clinical microbiology. 2007 Sep 1;45(9):2761-4. Google Scholar, DOI: 10.1128/JCM.01228-07

15. Benson DR, Stephens DW, Clawson ML, Silvester WB. Amplification of 16S rRNA genes from Frankia strains in root nodules of Ceanothus griseus, Coriaria arborea, Coriaria plumosa, Discaria toumatou, and Purshia tridentata. Applied and environmental microbiology. 1996 Aug 1;62(8):2904-9. Google Scholar

16. Tilahun B, Tesfaye A, Muleta D, Bahiru A, Terefework Z, Wessel G. Isolation and molecular identification of lactic acid bacteria using 16s rRNA genes from fermented Teff (Eragrostis tef (Zucc.)) dough. International journal of food science. 2018 Jan 1;2018.; doi.org/10.1155/2018/8510620. Google Scholar

17. Madoroba E. Molecular characterization and population dynamics of lactic acid bacteria during the fermentation of sorghum (Doctoral dissertation, University of Pretoria). Google Scholar, http://hdl.handle.net/2263/28898

18. Altschul SF, Gish W, Miller W, Myers EW, Lipman DJ. Basic local alignment search tool. Journal of molecular biology. 1990 Oct 5;215(3):403-10. Google Scholar, https://doi.org/10.1016/So022-2836(05)80360-2

19. Tamura K, Nei M. Estimation of the number of nucleotide substitutions in the control region of mitochondrial DNA in humans and $\begin{array}{llllll}\text { chimpanzees. Molecular biology and evolution. } 1993 \text { May } & \text {; 10(3):512-26. }\end{array}$ https://doi.org/10.1093/oxfordjournals.molbev.a040023

20. Aritua V, Parkinson N, Thwaites R, Heeney JV, Jones DR, Tushemereirwe W, Crozier J, Reeder R, Stead DE, Smith J. Characterization of the Xanthomonas sp. causing wilt of enset and banana and its proposed reclassification as a strain of X. vasicola. Plant pathology. 2008 Feb;57(1):170-7. Doi: 10.1111/j.1365-3059.2007.01687. Google Scholar

21. Young JM, Park DC, Shearman HM, Fargier E. A multilocus sequence analysis of the genus Xanthomonas. Systematic and applied microbiology. 2008 Oct 1;31(5):366-77. Google Scholar, https://doi.org/10.1016/j.syapm.2008.06.004

22. Studholme DJ, Wasukira A, Paszkiewicz K, Aritua V, Thwaites R, Smith J, Grant M. Draft genome sequences of Xanthomonas sacchari and two banana-associated xanthomonads reveal insights into the Xanthomonas group 1 clade. Genes. 2011 Dec;2(4):1050-65. Google Scholar, https://doi.org/10.3390/genes2041050

23. Kumar S, Stecher G, Tamura K. MEGA7: molecular evolutionary genetics analysis version 7.0 for bigger datasets. Molecular biology and evolution. 2016 Mar 22;33(7):1870-4. Google Scholar, https://doi.org/10.1093/molbev/msw054 
24. Adriko J, Aritua V, Mortensen CN, Tushemereirwe WK, Mulondo AL, Kubiriba J, Lund OS. Biochemical and molecular tools reveal two diverse Xanthomonas groups in bananas. Microbiological Research. 2016 Feb 1;183:109-16. Google Scholar, https://doi.org/10.1016/j.micres.2015.12.002

25. Alvarez AM. Integrated approaches for detection of plant pathogenic bacteria and diagnosis of bacterial diseases. Annual Review of Phytopathology. 2004 Sep 8;42:339-66. Google Scholar 